\title{
A large swelling of the tongue
}

\author{
Jay Gopal Ray, ${ }^{1,2}$ Sourav Bhattacharya, ${ }^{3}$ Basudev Mahato, ${ }^{3}$ Sanjit Mukherjee, ${ }^{2}$ Keya Chaudhuri ${ }^{2}$
}

1Department of Oral and Maxillofacial Pathology, Dr R Ahmed Dental College and Hospital, Kolkata, WestBengal, India;
2Department of Molecular and Human Genetics, Indian Institute of Chemical Biology, Kolkata, West Bengal, India;
3Department of Oral Pathology, Dr R Ahmed Dental College and Hospital, Kolkata, India

Correspondence to Professor Jay Gopal Ray, jaygopalray@yahoo.co.in

\section{Summary}

Hyalinising clear cell carcinoma (HCCC) is an infrequent distinct histological subtype of clear cell adenocarcinoma encountered in minor salivary glands which can be confused with a variety of clear cell-rich tumours. The entity of HCCC should be considered in patients presenting with well-circumscribed longstanding nodular enlargement without any other significant abnormality. HCCC is often difficult to diagnose due to its unusual presentation. This report presents a male patient who reported with a complaint of 2 month history of a large swelling on the tongue. The clinical, radiological, histological and immunohistochemical findings, confirmed the diagnosis of HCCC.

\section{BACKGROUND}

Hyalinising clear cell carcinoma (HCCC) is a rare salivary gland neoplasm often difficult to detect due to its unusual presentation. Moreover it is mostly presented in the oral cavity including the palatal region. HCCC on tongue is a very rare event and till date very few cases is present in literature.

\section{CASE PRESENTATION}

A 42-year-old male presented to the Department of Oral Pathology, Dr R Ahmed Dental College and Hospital, with a 2 month history of non-ulcerated smooth surface dome shaped swelling of the tongue. He had a history of smoking cigarette of one pack per day for the last 20 years but no significant family history of any disorder. His general health was within normal limits however he was weak in appearance and had no previous history of any medication. Extra oral examination showed no deformity of the face. Right submandibular lymphadenopathy was present. Intraoral examination revealed a diffused soft $3 \times 4 \mathrm{~cm}$ non-tender, painless, non-compressible slowly enlarging growth involving the right side of the tongue mainly and crossing the midline. The surface is non-ulcerated and has normal mucosal color. On palpation, no pulsation could be felt. On aspiration, it was found negative. Primary diagnosis of Rhabdomyosarcoma was done based upon the clinical findings. The posterior-anterior view $\mathrm{x}$-ray chest shows patchy opacities in both lung fields. Complete blood count was within normal limits. An incisional biopsy was done under local anaesthesia and presented with a soft gelatinous and gritty material. Significant vascularity was encountered preoperatively during the incisional biopsy procedure. Primary medication of antibiotics and analgesics was given for the immediate post operative period and the patient was recalled after 6 day for the report.

\section{INVESTIGATIONS}

Light microscopic evaluation of the biopsised specimen stained with $\mathrm{H} / \mathrm{E}$ revealed (figure $1 \mathrm{~B}$ ) a poorly circumscribed, invasive, heterogenous mass of clear cells showing hyperchromatic spindle shaped eccentric nuclei separated by thick eosinophillic hyalinised basement membrane like material. Perineural invasion by malignant cells was also noted. Periodic acid-Schiff (PAS) staining was positive however, PAS-diastase and mucicarmine showed negative staining, immunohistochemicaly cytokeratin A1/A3 was positive
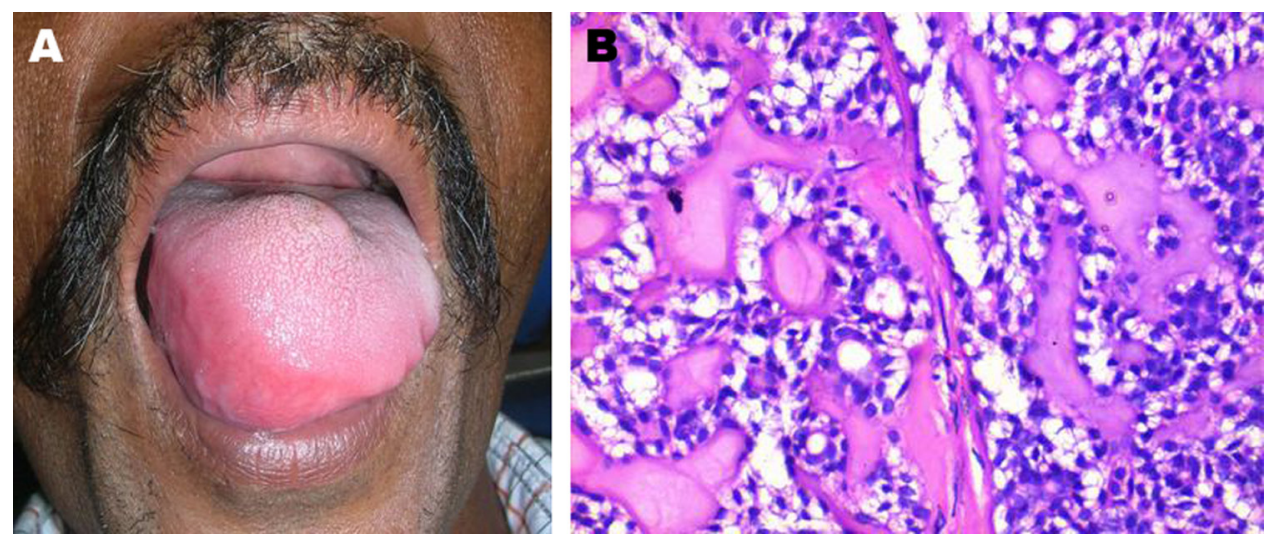

Figure 1 Hyalinising clear cell carcinoma A) On inspection. B) On histopathological examination (H\&E stain; x40 magnification). 


\section{BMJ Case Reports}

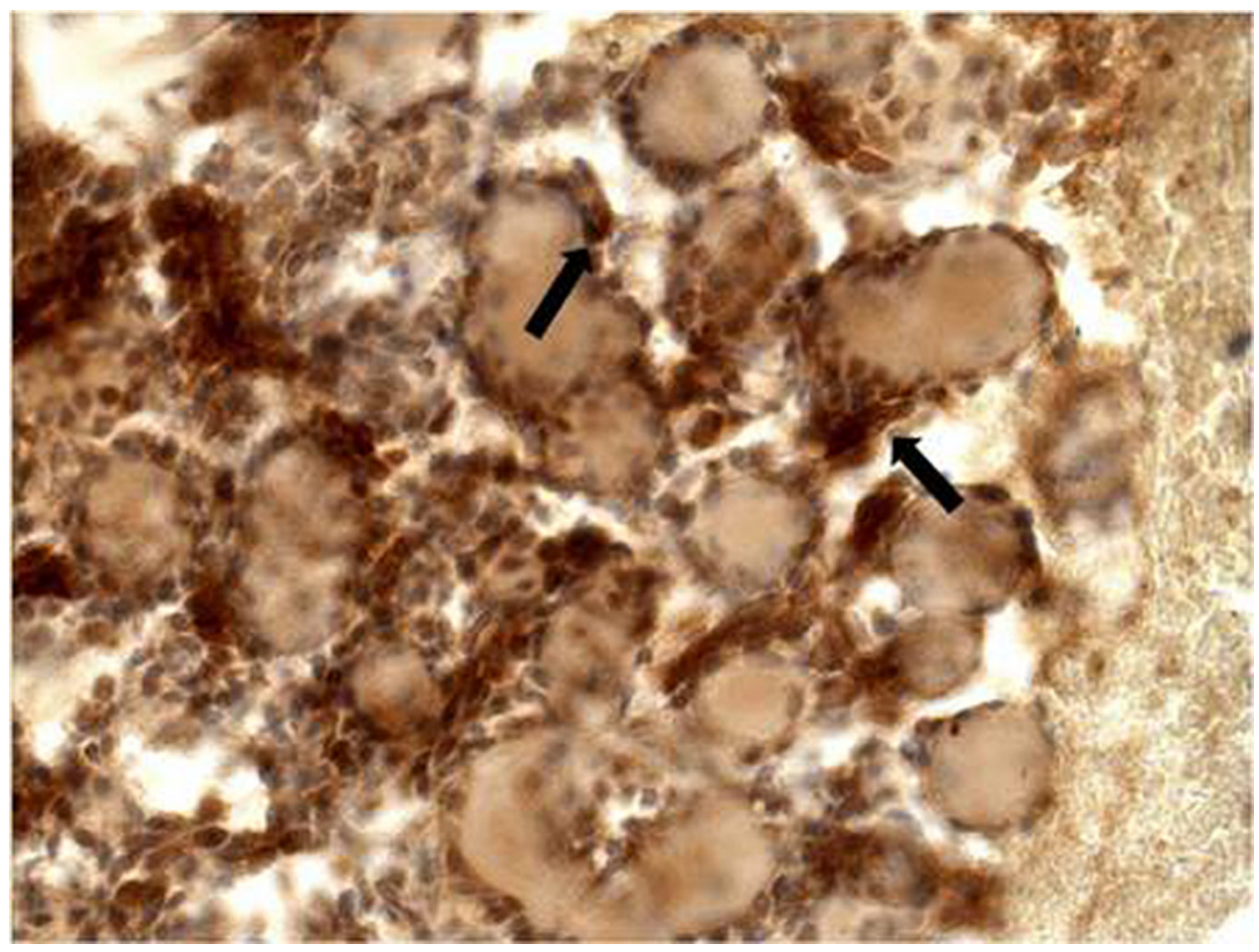

Figure 2 Photomicrographs of cytokeratin AE1/AE3 positive stained hyalinising clear cell carcinoma sections.

(figure 2). Histological and immunohistochemical studies suggested HCCC of the tongue. ${ }^{2}{ }^{2}$ The patient was referred with the final diagnosis to department of oncology but failed to report. Therefore, no further follow-up was available.

\section{DISCUSSION}

HCCC accounts for less than $1 \%$ of all salivary gland tumours and majority in females. The reported lower age limit is 24 years whereas the upper limit is 78 years (mean age was 51.7 years). ${ }^{3}$ Primarily these arise from the minor salivary glands including the hard palate, tongue, buccal mucosa, etc. whereas, some rare locations include jaw bones, subglottic larynx, nasopharynx and tonsillar region. ${ }^{3}$ HCCC is typically characterised by presence of a monomorphic population of undifferentiated cells with optically clear cytoplasm. ${ }^{13}$ Clear cells can be seen in different oral lesions histopathologically like clear cell carcinoma, clear cell melanocytic tumour, mucoepidermoid carcinoma, epimyoepithelial cell tumour, acinic cell carcinoma, clear cell odontogenic tumours and metastatic tumours. Since, the cells in this present tumour are highly positive to cytokeratin a1/a3 most of the other tumours are excluded considering the fact cytokeratin expression is highest in tumours of epithelial origin. One common characteristic reported in all reports is that there was no significant correlation between morphologic features and tumor behavior. About 25 tumour markers have been tested for immunopositivity/negativity to rule out other pathological conditions, out of these positive cytokeratin A1/A3, and negative mucin can be used as strong marker of HCCC. ${ }^{3}$
HCCC is a infrequent distinct histological subtype of clear cell adenocarcinoma encountered in minor salivary glands which can be confused with a variety of clear cellrich tumours. The entity of HCCC should be considered in patients presenting with diffused longstanding nodular enlargement of tongue without any other significant abnormality despite the indolent nature of the disease appropriate multi-disciplinary treatment is needed.

\section{Learning points}

- HCCC of tongue often is difficult to diagnose by the nature of its presentation.

- HCCC should be considered in patients presenting with diffused longstanding nodular enlargement of tongue.

- Positive cytokeratin $\mathrm{A} 1 / \mathrm{A} 3$, and negative mucin can be used as strong marker of HCCC.

Competing interests None.

Patient consent Obtained.

\section{REFERENCES}

1. Pujary K, Rangarajan S, Nayak DR, et al. Hyalinizing clear cell carcinoma of the base of tongue. Int J Oral Maxillofac Surg 2008;37:93-6.

2. Masilamani S, Rao S, Chirakkal $P$, et al. Hyalinizing clear cell carcinoma of the base of tongue: a distinct and rare entity. Indian J Pathol Microbiol 2011;54:167-9.

3. Solar AA, Schmidt BL, Jordan RC. Hyalinizing clear cell carcinoma: case series and comprehensive review of the literature. Cancer 2009;115:75-83. 


\section{BMJ Case Reports}

This pdf has been created automatically from the final edited text and images.

Copyright 2011 BMJ Publishing Group. All rights reserved. For permission to reuse any of this content visit http://group.bmj.com/group/rights-licensing/permissions.

BMJ Case Report Fellows may re-use this article for personal use and teaching without any further permission.

Please cite this article as follows (you will need to access the article online to obtain the date of publication).

Ray JG, Bhattacharya S, Mahato B, Mukherjee S, Chaudhuri K. A large swelling of the tongue. BMJ Case Reports 2011;10.1136/bcr.09.2011.4846, Published XXX

Become a Fellow of BMJ Case Reports today and you can:

- Submit as many cases as you like

- Enjoy fast sympathetic peer review and rapid publication of accepted articles

- Access all the published articles

- Re-use any of the published material for personal use and teaching without further permission

For information on Institutional Fellowships contact consortiasales@bmjgroup.com

Visit casereports.bmj.com for more articles like this and to become a Fellow 